private sector, where counselling has been less geared towards offering alternatives to abortion than to discussing ways and means of achieving it It seems right that patients who cannot afford private health care should be treated in the same way by the NHS. Proper counselling, which must include a discussion of the alternatives to abortion, is equally important in both sectors, but the ultimate choice should be in the hands of the woman herself and not subject to doctors' different interpretations of the law.

What is really depressing about the abortion scene in England and Wales is the rise in unplanned pregnancies and hence abortions at a time when contraception has never been more effective or more easily available.

MICHAEL BRUDENELI

London W:N $1 \mathrm{DE}$

1 Paintin D. Abortion in the first trimester. BMf 1992;305:967-8 (24 October.)

2 Correspondence. Abortion in the first trimester. BMF 1992;305: 1221-2. (14 November.)

\section{Screening for Down's syndrome}

EDITOR,-Women are selected for antenatal diagnosis of Down's syndrome if they are at high enough risk of the disorder to warrant the hazards and cost. Until recently selection was based largely on maternal age, but maternal serum testing and ultrasound screening are now also used.' Wald et al have reported on the extent of serum screening in England and Wales.' A national survey that carried out provides information on both methods.

Last January I sent a questionnaire to each health authority in England and Wales and the corresponding bodies in Scotland, Northern Ireland, Guernsey, Jersey, and the Isle of Man (taken from the Medical Directory). For simplicity each is referred to here as a district. Information was requested on current practice and changes being considered for the coming year, including whether women (not necessarily all ages) were routinely offered screening of multiple serum markers, reinterpretation of the serum $\alpha$ fetoprotein concentration used in screening for neural tube defects, and ultrasound screening.

I received replies from all 213 districts with obstetric units. In 17 practice differed among the units, and I regarded a district as using a specified method if at least one unit used it. The table show that not only has serum screening for Down's syndrome become established in the United Kingdom and is projected to become widely available in the future but use of ultrasound screening is also common and set to expand. Of the 52 districts that

Methods of screening for Down's syndrome used in districts in United Kingdom

\begin{tabular}{|c|c|c|c|c|}
\hline & \multicolumn{2}{|c|}{ Serum screening } & \multirow[b]{2}{*}{$\begin{array}{l}\text { No serum } \\
\text { screeningt }\end{array}$} & \multirow[b]{2}{*}{ All } \\
\hline & $\begin{array}{l}\text { Multiple } \\
\text { markers }\end{array}$ & $\begin{array}{c}\alpha \\
\text { Fetoprotein }\end{array}$ & & \\
\hline \multicolumn{5}{|c|}{ Current practice } \\
\hline $\begin{array}{l}\text { Ultrasound } \\
\text { screening }\end{array}$ & 21 & 14 & 17 & 52 \\
\hline $\begin{array}{l}\text { No ultrasound } \\
\text { screening }\end{array}$ & 59 & 39 & 63 & 161 \\
\hline Total & 80 & 53 & 80 & 213 \\
\hline \multicolumn{5}{|c|}{ Projected practice $\neq$} \\
\hline $\begin{array}{l}\text { Ultrasound } \\
\text { screening }\end{array}$ & 55 & 6 & 10 & 71 \\
\hline $\begin{array}{l}\text { No ultrasound } \\
\text { screening }\end{array}$ & 108 & 17 & 17 & 142 \\
\hline Total & 163 & 23 & 27 & 213 \\
\hline
\end{tabular}

${ }^{\star}$ Currently all use human chorionic gonadotrophin and $\alpha$ fetoprotein, 47 with unconjugated oestriol and 34 without. tCurrently 33 measure $\alpha$ fetoprotein but do not use it in screening for Down's syndrome.

$\ddagger$ Those currently using the screening method or considering it for the future. used ultrasound screening, 42 acted on anomalies associated with Down's syndrome identified in a routine scan (for example, renal dilatation or choroid plexus cysts) and 41 on biometric variables (femur length (28) and nuchal thickness (31)).

The survey suggests that many districts may soon be using both screening methods, and detection would be maximised if the results of one were taken into account when the other was interpreted. Information is not available on the correlation, if any, between the biochemical and ultrasound markers so this cannot be done formally, but that is not the main obstacle to a combined approach rather it is timing. Serum screening is usually done at 15-17 weeks' gestation and a scan for anomalies at 18-20 weeks. High rates of detection of nuchal oedema have been reported with ultrasound screening at 10-14 weeks' gestation, ${ }^{3-5}$ and serum screening can also be done before 15 weeks, ${ }^{\circ}$ so combined screening at about 13 weeks is feasible. The scan at 18-20 weeks would still, however, be needed to detect structural abnormalities, and the additional cost of an early scan might be considered to be too high.

HOWARD CUCKLE Institute of Epidemiology and Health Services Research, Department of Clinical Medicine,

University of Leeds,

Leeds LS2 9LN

1 Mutton DE, Alberman E, Ide R, Bobrow M. Results of first year 1989) of a national register of Down's syndrome in Englan and Wales. BMF 1991:303:1295-

Wald N, Wald K, Smith D. The extent of Down's syndrom screening in Britain in 1991. Lancet 1992;340:49

3 Nicolaides KH, Azar G, Byrne D, Mansur C, Marks K. Fetal nuchal translucency: ultrasound screening for chromosom defects in first trimester of pregnancy. BMF 1992;304:867-9.

4 Schulte-Vallentin $M$, Schindler $H$. Non-echogenic nuchal edrom 21 screening. Lancet 1992:339: 1053.

5 Van Zalen-Sprock MM, van Vugt JMG, van Geijn HP. Nonechogenic nuchal oedema as a marker in trisomy 21 screening. Lancet 1992:339:1480-1.

6 Cuckle H, Lilford R. Antenatal screening for Down's syndrome. BMF 1992;305:1017. (15 August.)

\section{Cycle helmets}

EDITOR,- The only evidence on the effects of increased helmet wearing among populations of cyclists shows no significant (or negative) benefits in the rates of head injury. Time series analysis of increased helmet wearing in the United States found no reduction in head injuries and deaths of cyclists, and Rodgers stated that "bicycle-related fatalities are positively and significantly associated with increased helmet use."

The official study of the effects of compulsory helmet wearing in Victoria, Australia, does not show any significant benefit from passage of the law enforcing helmet wearing (A P Vulcan et al, 36th annual proceedings of American Association for Automotive Medicine, 5 October 1992). During the year studied the number of people killed or admitted to hospital as a result of all road accidents was $12 \%$ below the previous year's figure. On the basis of the figures we have for the reduction in cycle use, it seems that the law resulted in an increase in the rate of injuries other than injuries among cyclists.

The law in Victoria resulted in a reduction in the numbers of people cycling, with consequent disadvantages for public health: reductions were $41 \%$ among recreational cyclists and $37 \%$ among commuters in the Melbourne area and $44 \%$ among 12-17 year olds in Victoria (A P Vulcan et al, 36th annual proceedings of American Association for Automotive Medicine, 5 October 1992). A considerable reduction also occurred when compulsory helmet wearing was introduced in New South Wales. ${ }^{*}$

The official report never considers the possibility of adaptive or compensatory behaviour by cyclists or other road users to explain the apparent failure of the law. This follows the trend in neglecting the effects of other regulations which appear not only to have failed but to have increased danger to vulnerable road users. ${ }^{2}$ Reducing danger to cyclists will require more than the so called primary measures outlined in Helen $\mathrm{R}$ Trippe's editorial': necessary measures will have attention diverted away from them by (incomplete) concern about helmets.

There has been increasing concern about the massive health disadvantage of extensive use of cars and lorries, and the excessive dependency of our society on these modes of transport." The medical establishment has failed to address the problem properly. This should be remedied by a call for a major reduction in our dependency on motor vehicles and opposing moves to compulsory wearing of cycle helmets.

JOHN WHITELEGG ROBERT DAVIS

Department of Geography,

University of Lancaster,

Lancaster LAl 4 YB

1 Rodgers G. Reducing bicycle accidents: a re-evaluation of the impacts of the CPSC bicycle standard and helmet use. foumal of Products Liability 1988;11:307-17.

2 Davis RAE. Death on the streets: cars and the mythology of road safety. Hawes, North Yorkshire: Leading Edge (in press).

3 Morgan M, Peberdy J, Rogerson P. Bicycle helmet usage rates in Victoria, 1990 to 1991, and other bicycle safety factors. Victoria: Vic Roads, 1991. (Report GR 91-9.)

4 Govt survey shows decline in cycling [editorial]. Australian Cyclist 1992 Aug-Sept.

Trippe HR. Helmets for pedal cyclists. BM7 1992;305:843-4. (10 October.)

6 Whitelegg J. Transport for a sustainable future: the case for Europe. London: Belhaven Books (in press)

\section{Care in the community in Westminster}

EDITOR,-Contrary to Minerva's gloomy predictions, ${ }^{1}$ Westminster is well prepared for taking on care in the community next year. In view of the national shortage of occupational therapists the problem of delays in assessments for aids and adaptations in the home is not peculiar to Westminster. Both health and local authorities are examining how best to use scarce resources most effectively to speed up the process.

Wheelchairs are not, in fact, a responsibility of the local authority. Occupational therapists canand do--advise and assess users, but the supply of wheelchairs is down to the NHS, and both Riverside and Parkside Health Authorities have a wheelchair service.

The underlying issue is how to improve the coordination of services so that users are not "victimised" by organisational boundaries. Westminster has addressed this by developing an assessment and care management service, by which packages of services will be tailor made to meet individual needs. I am confident that this, together with an increase in general practice fundholders, will be the key to more responsive services.

JENNY BIANCO

City of Westminster Social Services Committee,

London SW1E 6QP

1 Minerva. $B M 7$ 1992;305:1106. (31 October.)

\section{Dentists and the NHS}

EdiTor,-Minerva reports that in North America people with less discretionary income do not choose to spend their money on dentistry. ${ }^{1}$ With the current dispute between the government and dentists in Britain over fees for NHS work, I believe that many patients in Britain are likely to 